\title{
Physicochemical properties and microencapsulation process of rice fermented with Bacillus subtilis CBD2
}

\author{
Dae-Hoon Lee, Hye-Mi Park, Joo-Heon Hong* \\ Department of Food Science and Technology, Catholic University of Daegu, Gyeongsan 712-702, Korea
}

\section{Bacillus Subtilis CBD2로 배양된 백미 발효물의 미세캡슐 제조 및 물리화학적 특성}

\author{
이대훈 · 박혜미·홍주헌* \\ 대구가톨릭대학교 식품공학전공
}

\begin{abstract}
This study was conducted to examine the physicochemical properties and micro-encapsulation process of rice fermented with Bacillus subtilis CBD2. The viable bacterial cell, $\mathrm{pH}$, and amylase activity of the rice liquid culture were $7.61 \log \mathrm{CFU} / \mathrm{mL}$, pH 5.08 and 159.43 units $/ \mathrm{mL}$, respectively. The micro-encapsulated rice liquid culture was manufactured via spray drying with different forming agents: i.e., alginic acid $1.0 \%$ and chitosan $0.3 \%, 0.5 \%$, and $1.0 \%$. The moisture contents of the spray-dried powders were approximately $2.90 \sim 3.68 \%$. The color of the $L$ and a value decreased whereas that of the $b$ and $\triangle E$ value increased. The particle size and outer topology of the spray-dried rice liquid culture were $48.13 \sim 68.48 \mu \mathrm{m}$ and globular, respectively. The water absorption index of the spray-dried powder $(2.40 \sim 2.65)$ was lower than that of the freeze-dried powder (2.66). The water solubility index of the spray-dried powder $(9.17 \sim 10.89 \%)$ was higher than that of the freeze-dried powder $(7.12 \%)$. The in vitro dissolution was measured for five hours in $\mathrm{pH} 1.2$ simulated gastric fluid, and pH 6.8 and pH 7.4 simulated intestinal fluids, using a dissolution tester at $37^{\circ} \mathrm{C}$ with $50 \mathrm{rpm}$ agitation. The amylase survival in the fermented rice was $85.93 \%$ through the spray-drying and it was very effectively controlled.
\end{abstract}

Key words : Bacillus subtilis CBD2, rice, microencapsulation, amylase activity, physicochemical properties

\section{서 론}

최근 생활수준이 향상됨에 따라 소비자들의 식습관이 영양공급이라는 식품 고유 기능 이외에 건강증진과 질병 치료 등의 기능을 가진 식품자원에 대한 관심이 늘어나고 있다(1). 식품 자원 중 쌀 $($ Oryzae sativa L.)은 밀 및 옥수수와 더불어 세계 3대 작물로서 우리나라의 경우 주요 곡물자원 중의 하나이며 농가소득의 $30 \%$, 농업소득의 $70 \%$ 를 차지하 는 농가경제의 중요한 소득원으로 알려져 있으나(2), 쌀시

*Corresponding author. E-mail : jhhong@cu.ac.kr Phone : 82-53-850-3218, Fax : 82-53-850-3218

Received 27 January 2015; Revised 10 March 2015; Accepted 16 March 2015.

Copyright (c) The Korean Society of Food Preservation. All rights reserved.
장 개방 및 소비자 기호도 변화에 따른 1 인당 연간 소비량은 감소하고 있어 소비를 증가시키기 위해 주식뿐만이 아닌 가공제품 개발 및 다양화를 위한 노력이 요구되고 있다(3). Bacillus 속 미생물 유래의 amylase는 식품산업에 있어 식품 원료를 가공하거나 특성을 개선하기 위해 오래전부터 전분 을 가공하는 핵심 효소로서 지속적으로 활용되어져 왔다 (4). 하지만 효소는 대부분 단백질로 구성되어 열과 강산, 강알칼리에 약하고 인체 내 활성이 불안정한 것으로 알려져 있다. 이러한 특징을 가진 효소는 생산 단가가 높고 반응공 정에 있어서 많은 어려움을 가져다주어, 이와 같은 문제점 을 해결하는 방법 중 효소의 안정화가 매우 유용한 방법으 로 인정되어 이에 대한 연구가 활발히 진행되고 있다 $(5,6)$ 분무건조 공정은 유용성분의 보호를 목적으로 미세캡슐을 만드는 상업화된 방법 중 가장 보편화 된 것으로 그 생산량 도 가장 많아 여러 분야에서 다양하게 이용되고 있으며, 
분무 건조된 입자는 피복물질 종류와 조성에 의해 그 특성 이 결정된다고 보고되고 있다(7-9).

미세캡슐화를 위해 사용된 피복물질로 alginic acid는 음 이온의 다당류이며 두 가지 종류의 당 잔기, 즉 D-mannuronate 와 L-gluronate를 함유한 직선형 block copolymer이다. 이러 한 alginic acid는 낮은 $\mathrm{pH}$ 에서 수축이 일어나고, 중성에서 팽윤 및 분해가 일어남으로써 산성 치환기의 영향을 효과적 으로 차단하고 유용물질 방출을 조절 할 수 있어 의약품, 화장품 및 식품 등의 첨가제나 정제의 결합제로 활용되고 있다(10). 그러나 alginic acid는 phosphate와 같은 양이온 킬레이트제(chelate agent)에 의해 생체촉매의 격리효과가 낮으며 효모, 동·식물세포 등과 같이 크기가 큰 생체촉매의 고정화에만 효과적으로 사용될 수 있어 사용범위가 제한적 이다(11). 키토산은 게나 새우 등 갑각류의 껍질을 이루는 주성분인 키틴의 N-아세틸기를 탈아세틸화하여 아미노기 (amino group)로 치환시켜 얻어지는 생분해성 천연 고분자 물질이며(12), 폴리- $\beta(1,4)-\mathrm{N}$-아세틸-D-글루코사민을 기본 단위로 하여 이루어진 다당체이다. 키토산은 phosphate와 같은 킬레이트제에 안정하고 무독성, 효소 고정화제 및 점 막부착제로서의 기능이 알려져 있다(13). 이러한 피복물질 들은 각각 장점과 단점을 가지므로 이들 물질을 여러 형태 로 조합할 경우, 단독으로 사용할 때 보다 향상된 결과를 보여줄 수 있다(14).

따라서 본 연구에서는 백미를 B. subtilis $\mathrm{CBD} 2$ 로 배양한 발효물을 이용하여 곡류 효소함유 식품을 개발하고자 하였 으며 발효물에 함유되어 있는 amylase의 안정화를 위해 알긴산과 키토산을 피복물질로 사용하여 미세캡슐 분말로 제조하였고 미세캡슐화 한 분말의 물리화학적 특성 및 amylase 활성을 조사하였다.

\section{재료 및 방법}

\section{실험재료}

본 실험에 사용된 백미는 경상북도 의성군에서 2013년 10 월에 재배된 것을 구입하여 건식 분쇄기(FM- $909 \mathrm{~W}$, Hanil Co., Sejong, Korea)로 분쇄한 다음 표준망체(0.074 $\mathrm{mm}$, Chung Gye Sang Gong Sa, Seoul, Korea)를 통과시킨 분말을 사용하였다.

\section{백미 발효물 제조}

발효를 위해 사용된 미생물은 된장으로부터 분리 동정한 Bacillus subtilis $\mathrm{CBD} 2$ 를 이용하였다(15). Starter는 백미 분 말 $20 \mathrm{~g}$ 을 삼각플라스크에 넣고 멸균 한 다음 $40 \mathrm{~mL}$ 의 멸균수를 첨가하여 사용하였으며 B. subtilis $\mathrm{CBD} 2$ 는 nutrient broth(NB, Difco, Detroit, MI, USA)에 접종하여 $37^{\circ} \mathrm{C}$ 에서 24 시간 배양하여 사용하였다. 백미 발효는 미리
배양된 B. subtilis $\mathrm{CBD} 2$ starter액을 $2 \%$ 접종 후 $37^{\circ} \mathrm{C}$ 배양기 (IL-21, Jeio Tech Co., Daejeon, Korea)에서 96시간까지 발효 하여 실험용 시료로 사용하였다.

\section{미세캡슐화}

분무건조공정을 이용한 미세캡슐의 제조는 백미 발효물 $500 \mathrm{~mL}$ 에 alginic acid(Sigma-Aldrich Co., St. Louis, MO, USA) $1.0 \%$ (SD-A) 와 chitosan(223 kDa, Kittolife, Seoul, Korea)을 각각 $0.3 \%(\mathrm{SD}-\mathrm{Ach} 0.3), 0.5 \%$ (SD-Ach0.5) 및 $1.0 \%$ (SD-Ach1.0)를 첨가한 다음 고압균질기(HG-15D, DAIHAN scientific Co., Wonju, Korea)를 이용하여 4,000 $\mathrm{rpm}$ 에서 15 분간 균질화하였다. 제조된 균질액은 주입 온도 $160^{\circ} \mathrm{C}$, 방출 온도 $110^{\circ} \mathrm{C}$ 로 설정하였고, 분무속도는 17,000 $\mathrm{rpm}$ 에서 시료공급속도는 $12 \mathrm{~mL} / \mathrm{min}$ 의 조건으로 아토마이 저(atomizer)가 장착된 분무건조기(KL-8, Seogang Engineering Co., Ltd, Cheonan, Korea)를 이용하여 미세캡슐 분말을 제 조한 다음, $-70^{\circ} \mathrm{C}$ 이하의 암소에 보관하면서 분석용 시료 로 사용하였다. 대조구로는 피복물질을 첨가하지 않고 동 결건조기(FreeZone-2.5, Labconco Co., Kansas, MO, USA) 를 이용하여 건조한 분말을 사용하였다.

\section{생균수 측정}

생균수 측정은 배양액 $1 \mathrm{~mL}$ 에 $0.85 \%$ sodium chloride (Duksan Pure Chemicals, Seoul, Korea) 용액 $9 \mathrm{~mL}$ 를 혼합하 여 10 배 희석법으로 희석한 다음, 각각의 희석액 $100 \mu \mathrm{L}$ 를 $1.5 \%$ agar(Sigma-Aldrich Co.)가 첨가 된 nutrient broth(NB, $\mathrm{Difco}$.)에 접종하여 평판 측정법으로 생균수를 측정하였다. 각각의 plate는 $37^{\circ} \mathrm{C}$ 배양기(Jeio Tech Co.)에서 24 시간 배양 한 다음 형성된 colony 수를 계측하고, colony에 희석배수를 곱하여 시료 $\mathrm{mL}$ 당 colony forming unit(CFU)로 나타내었다.

\section{Amylase 활성 측정}

Amylase 활성 측정은 $50 \mathrm{mM}$ sodium phosphate(Duksan Pure Chemicals.) 완충용액(pH 7.0)에 $0.5 \%$ soluble starch (Sigma-Aldrich Co.)를 기질로 이용하여 제조된 용액 0.5 $\mathrm{mL}$ 에 시료 $0.5 \mathrm{~mL}$ 를 효소액으로 첨가하여 $37^{\circ} \mathrm{C}$ 에서 30 분 간 환류수조(BS-31, Jeio Tech Co.)에서 반응시켰다. 이 때 생성된 환원당의 함량은 3,5-dinitrosalicylic acid(DNS, Sigma-Aldrich Co.)방법(16)으로 측정하였으며, 본 연구에 서 효소 활성의 1 unit은 1 분에 $1 \mu \mathrm{mol}$ 의 glucose(SigmaAldrich Co.)를 생산하는 효소량으로 정의하였다.

\section{수분함량}

수분함량 측정은 분말을 페트리디쉬에 담아 적외선 수분 측정기(MB-45, Moisture analyzer, INC., Ohaus, USA)를 이 용하여 $105^{\circ} \mathrm{C}$ 에서 분말의 수분함량이 항량에 도달할 때까 지 건조하여 측정하였다. 


\section{색도 측정}

색도 측정은 분말을 표준색도가 $\mathrm{Y}=94.5, \mathrm{a}=0.18, \mathrm{~b}=0.32$ 로 보정된 색차계(Chromameter CR200, Minolta Co., Osaka, Japan)를 사용하여, 밝기를 나타내는 L(lightness), 적색도를 나타내는 a(redness), 황색도를 나타내는 b(yellowness)값을 측정하였으며, 색차 $\triangle \mathrm{E}$ 는 동결건조 분말을 대조구로 하여 아래와 같이 계산하였다.

$$
\triangle \mathrm{E}=\sqrt{\triangle L^{2}+\Delta a^{2}+\Delta b^{2}}
$$

\section{입자크기 및 입자표면 구조 측정}

입자크기 측정은 레이저입도분석기(LS-13-320, Beckman coulter, Fullerton, CA, USA)를 이용하여 isopropyl alcohol에 분산시켜 측정하였다. 입자표면구조는 각 시료에 gold ion coating한 후 주사형 전자현미경(S-4800, Hitachi highTechnologies Co., Tokyo, Japan)을 이용하였다. 전자현미경 을 이용한 관찰은 $3.0 \mathrm{kV}$ 에서 1,000 배 비율로 관찰하였다.

\section{수분흡수지수(WAI) 및 수분용해지수(WSI) 측정}

수분흡수지수(water absorption index, WAI) 및 수분용해지 수(water solubility index, WSI) 측정은 phillips의 방법(17)을 변형하여 측정하였다. 동결건조 및 미세캡슐 분말 $0.5 \mathrm{~g}$ 에 $20 \mathrm{~mL}$ 증류수를 첨가하여 $3,000 \mathrm{rpm}$ 에서 20분간 원심분리 (VS-6000CFN, Vision scientific Co., Bucheon, Korea) 한 후 침전물은 수분흡수지수로 사용하였으며, 상등액은 미리 무게 를 구한 수기에 분리하여 $105^{\circ} \mathrm{C}$ 에서 4 시간 동안 건조시킨 고형분을 수분용해지수로 사용하여 아래와 같이 계산하였다.

$$
\begin{aligned}
& \text { 수분흡수지수 }(\mathrm{WAI})=\frac{\text { 침 전물의 양 }}{\text { 시료의 양 }} \\
& \text { 수분용해지수(WSI, \%) }=\frac{\text { 상등액 고형분 의 양 }}{\text { 시료의 양 }} \times 100
\end{aligned}
$$

\section{인체 내 소화모델(in vitro)}

In vitro 인체 내 소화모델은 Hur 등(18)의 in vitro human digestion의 multi-step model을 일부 수정하여 이용하였으 며, 동결건조 및 분무건조 미세캡슐 분말의 amylase 활성 측정을 통해 인체 내 소화모델을 분석하였다. 사용된 액은 대한약전에 따라 당일 제조 하였으며, 위장액( $\mathrm{pH} 1.2)$ 은 $0.1 \mathrm{~N}$ hydrochloric acid( $\mathrm{HCl}$, Duksan Pure Chemicals.)을, 소장액 $(\mathrm{pH}$ 6.8) 및 대장액 $(\mathrm{pH}$ 7.4)은 $0.1 \mathrm{M}$ sodium phosphate(Duksan Pure Chemicals.) 완충용액을 사용하여 제조하였다. 반응은 환류수조(BS-31, Jeio Tech Co.)에서 $37^{\circ} \mathrm{C}, 50 \mathrm{rpm}$ 으로 진행되었으며, 먼저 삼각플라스크에 시료 $0.2 \mathrm{~g}$ 및 위장액 $12 \mathrm{~mL}$ 를 첨가하여 2시간 반응하였다. 이 후 소장액 $18 \mathrm{~mL}$ 를 첨가하여 1 시간 반응 한 다음 대장액
$6 \mathrm{~mL}$ 를 첨가하여 2시간 반응을 진행하였다. 각 용액 첨가 시 sodium bicabonate(Duksan Pure Chemicals.) 및 sodium hydroxide(Duksan Pure Chemicals.)를 사용하여 $\mathrm{pH}$ 를 보정 한 다음 amylase 활성을 측정하였다.

\section{통계처리}

실험결과는 3회 반복으로 행하여 평균 \pm 표준편차로 나타 내었으며 SPSS(19.0, SPSS Inc., Chicago, IL, USA)를 이용하 여 분산분석(ANOVA)을 실시하였으며, 각 측정 평균값의 유의성 $(\mathrm{p}<0.05)$ 은 Duncan's multiple range test로 검정하였다.

\section{결과 및 고찰}

\section{백미 발효물의 배양특성}

백미 발효물의 배양특성은 예비 실험을 통해 선정된 96 시간 발효 후의 생균수, $\mathrm{pH}$ 및 amylase 활성을 Table 1에 나타내었다. 백미에 B. subtilis $\mathrm{CBD} 2$ 를 $2 \%$ 로 접종하여 96 시간 발효한 결과 생균수는 $7.61 \log \mathrm{CFU} / \mathrm{mL}$ 이었고 $\mathrm{pH}$ 는 5.08을 나타내었다. 생균수는 Yang 등(19)의 B. subtilis $\mathrm{CBD} 2$ 를 이용한 곡류 발효물의 배양특성에서 미생물들이 곡류를 자기 증식에 효과적으로 이용함에 따라 96시간 이 후 $6.89 \log \mathrm{CFU} / \mathrm{mL}$ 로 생균수가 증가하였다고 보고하여 본 연구결과와 유사함을 알 수 있었다. 백미 배양물은 초기 에 비해 96시간 발효한 다음 $\mathrm{pH}$ 가 감소하였으며, 이는 미생 물에 의해 발효가 진행되면서 생성된 lactic acid와 acetic acid 등의 여러 가지 산의 생성과 관계가 있는 것으로 사료 된다(20). Amylase 활성은 $159.43 \mathrm{unit} / \mathrm{mL}$ 로 나타났으며, Park 등(21)의 곡물별 담자균 배양물의 효소활성에서 120시 간 발효한 다음 백미의 a-amylase 활성은 46.16 91.74 unit/mL를 나타내어 본 연구에서 배양된 백미 발효물의 활 성이 높게 나타남을 알 수 있었다.

Table 1. Viable bacteria cell, $\mathrm{pH}$, and amylase activity of the rice fermented with Bacillus subtilis CBD2

\begin{tabular}{cccc}
\hline Sample & $\begin{array}{c}\text { Viable bacteria cell } \\
(\log \mathrm{CFU} / \mathrm{mL})\end{array}$ & $\mathrm{pH}$ & $\begin{array}{c}\text { Amylase activity } \\
\text { (unit } / \mathrm{mL})\end{array}$ \\
\hline Fermented rice & $7.61 \pm 0.20$ & $5.08 \pm 0.15$ & $159.43 \pm 11.10$ \\
\hline
\end{tabular}

All the values are mean $\pm S D(n=3)$.

\section{수분함량 및 색도}

백미 발효물 동결건조 및 분무건조 미세캡슐 분말의 수 분함량 및 색도를 측정한 결과는 Table 2 와 같다. 수분함량 은 동결건조 분말에서 $2.30 \%$ 로 가장 낮은 함량을 나타내었 으며, 분무건조 미세캡슐 분말에서 $2.90 ~ 3.68 \%$ 로 키토산 함량이 증가함에 따라 높게 나타났다. Beom 등(22)의 수창 포 열풍 및 동결건조 분말의 수분함량에서 각각 8.67 
Table 2. Moisture, Hunter's color values, and particle size of the rice powders fermented with Bacillus subtilis CBD2

\begin{tabular}{ccccccc}
\hline \multirow{2}{*}{ Samples $^{1)}$} & $\begin{array}{c}\text { Moisture content } \\
(\%)\end{array}$ & \multicolumn{4}{c}{ Hunter's color value } & \multicolumn{2}{c}{$\begin{array}{c}\text { Particle size } \\
(\mu \mathrm{m})\end{array}$} \\
\cline { 3 - 6 } & $2.30 \pm 0.11^{\mathrm{c} 2)}$ & $95.85 \pm 0.58^{\mathrm{a}}$ & $-0.30 \pm 0.05^{\mathrm{a}}$ & $5.60 \pm 0.18^{\mathrm{d}}$ & - & $357.87 \pm 10.83^{\mathrm{a}}$ \\
FD & $2.90 \pm 0.21^{\mathrm{b}}$ & $96.18 \pm 0.58^{\mathrm{a}}$ & $-0.79 \pm 0.02^{\mathrm{b}}$ & $5.60 \pm 0.18^{\mathrm{d}}$ & $0.62 \pm 0.11^{\mathrm{d}}$ & $68.48 \pm 1.38^{\mathrm{b}}$ \\
SD-A & $3.56 \pm 0.28^{\mathrm{a}}$ & $95.70 \pm 0.27^{\mathrm{a}}$ & $-1.17 \pm 0.04^{\mathrm{c}}$ & $8.19 \pm 0.15^{\mathrm{c}}$ & $2.92 \pm 0.12^{\mathrm{c}}$ & $54.21 \pm 1.04^{\mathrm{c}}$ \\
SD-ACh0.3 & $3.68 \pm 0.19^{\mathrm{a}}$ & $95.92 \pm 0.10^{\mathrm{a}}$ & $-1.16 \pm 0.04^{\mathrm{c}}$ & $8.86 \pm 0.18^{\mathrm{b}}$ & $3.57 \pm 0.17^{\mathrm{b}}$ & $51.33 \pm 0.37^{\mathrm{d}}$ \\
SD-ACh0.5 & $3.83 \pm 0.20^{\mathrm{a}}$ & $92.25 \pm 0.47^{\mathrm{b}}$ & $-1.26 \pm 0.02^{\mathrm{d}}$ & $15.69 \pm 0.64^{\mathrm{a}}$ & $10.95 \pm 0.73^{\mathrm{a}}$ & $48.13 \pm 0.82^{\mathrm{e}}$ \\
SD-ACh1.0 & & &
\end{tabular}

${ }^{15} \mathrm{FD}$, freeze-dried powder; SD-A, spray-dried powder with $1.0 \%$ alginic acid added; SD-ACh0.3, spray-dried powder with $1.0 \%$ alginic acid and $0.3 \%$ chitosan added; SD-ACh0.5, spray-dried powder with $1.0 \%$ alginic acid and $0.5 \%$ chitosan added; and SD-ACh1.0, spray-dried powder with $1.0 \%$ alginic acid and $1.0 \%$ chitosan added.

${ }^{2)}$ Means $\pm \mathrm{SD}(\mathrm{n}=3)$ in each column (a-e) followed by the same letter do not significantly differ $(\mathrm{p}<0.05)$.

$16.62 \%$ 및 3.61 11.04\%로 나타났으며, Lee(23)의 국내 쌀 품종의 수분함량이 7.19 13.81\%로 나타나 본 연구에서 제 조된 백미 분말의 수분함량이 낮게 나타남을 알 수 있었다. 이는 분무 건조 공정에서 가열 공기 온도가 높아지면 열전 달 효율성의 증가로 인해 분말의 수분함량이 감소한다는 연구결과에 따라(24), 위생적이고 균일한 품질의 저장성 높은 분말을 얻을 수 있을 것으로 사료된다.

색도는 동결건조 분말 $\mathrm{L}$ 값, $\mathrm{a}$ 값 및 $\mathrm{b}$ 값이 각각 95.85 , -0.30 및 5.60을 나타내었으며, 분무건조 미세캡슐 분말에 서는 키토산 함량이 증가함에 따라 L값(92.25 96.18) 및 $\mathrm{a}$ 값(-0.79 -1.26)은 낮아지고 $\mathrm{b}$ 값(5.60 15.69)은 증가하는 경향을 나타내었다. 특히 동결건조 분말을 기준으로 본 $\triangle \mathrm{E}$ 값은 키토산 $0.3 \%$ 에서 2.92 로 가장 낮고 키토산 $1.0 \%$ 에서 10.95 로 가장 높게 나타나 키토산 함량이 증가할수록 색차 의 변화가 증가하였다. Lee와 $\mathrm{No}(25)$ 는 키토산 첨가 생면 연구에서 키토산 함량이 증가할수록 $\mathrm{L}$ 값은 낮아지고 $\mathrm{b}$ 값은 높은 경향을 나타내었으며 Kim 등(26)은 키토산 및 젤라틴 폴리머 필름 제조에서 색도는 키토산 함량이 증가할수록 $\mathrm{L}$ 값 및 $\mathrm{a}$ 값은 감소되었고 $\mathrm{b}$ 값은 반비례로 증가되어 본 연구 와 유사한 경향을 나타내었다.

\section{입자크기 및 입자표면구조}

백미 발효물 동결건조 및 분무건조 미세캡슐 분말의 입 자크기 및 입자표면구조를 Table 2 및 Fig. 1에 나타내었다. 입자크기는 동결건조 분말에서 $357.87 \mu \mathrm{m}$ 로 분무건조 미세 캡슐 분말에 비해 유의적으로 크게 분석되었으며, 미세캡 슐 분말의 입자크기는 48.13 68.48 $\mu \mathrm{m}$ 로 키토산 함량이 증가할수록 유의적으로 감소되는 경향이었다. Park 등(27) 은 키토산 분자량에 따른 $\beta$-carotene의 미세캡슐화 및 품질 특성에서 분자량별로 입자크기가 26.55 109.80 $\mu \mathrm{m}$ 의 범위 를 나타내었으며 분자량이 증가함에 증가한다고 보고하였 다. 본 연구에서는 입자크기가 $100 \mu \mathrm{m}$ 이하로 균일한 분포 를 보여주었고, 분무건조 공정을 통해 제조된 균일한 입자 크기의 미세캡슐 분말은 흐름성이 양호할 것으로 사료된다. 분무건조 미세캡슐 분말의 입자표면구조는 전반적으로
구형의 모양을 나타냄에 따라 흐름성이 양호할 것으로 사료 되며, 알긴산 단독 첨가군의 경우 매끈한 굴곡을 가진 표면 구조를 나타내었으나, 키토산 함량이 증가할수록 표면 굴 곡이 증가하는 경향을 나타내었다. Kim 등(28)은 부형제 종류에 따른 분말의 주사전자 현미경 관찰에서 입자 표면의 부드러운 구형이 아닌 움푹 들어간 자국들은 건조 과정 중에 입자들이 수축함에 따른 현상이라고 보고하였다.

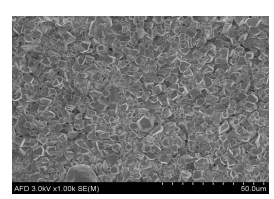

FD

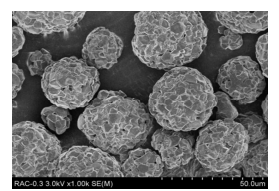

SD-ACh0.3

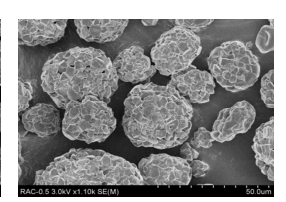

SD-ACh0.5

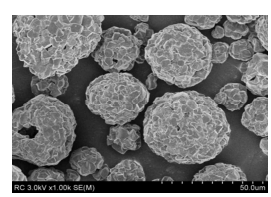

SD-A

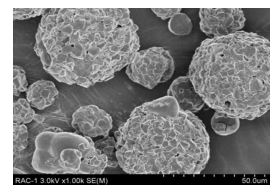

SD-ACh1.0
Fig. 1. Scanning electron microscopic photographs of the rice powders fermented with Bacillus subtilis CBD2 (magnification $\times 1,000$ ).

FD, freeze-dried powder; SD-A, spray-dried powder with $1.0 \%$ alginic acid added; SD-ACh0.3, spray-dried powder with $1.0 \%$ alginic acid and $0.3 \%$ chitosan added; SD-ACh0.5, spray-dried powder with $1.0 \%$ alginic acid and $0.5 \%$ chitosan added; and SD-ACh1.0, spray-dried powder with $1.0 \%$ alginic acid and $1.0 \%$ chitosan added.

\section{수분흡수지수 및 수분용해지수}

백미 발효물을 이용한 동결건조 및 분무건조 미세캡슐 분말의 수분흡수지수(WAI) 및 수분용해지수(WSI) 측정 결 과는 Table 3 과 같다. 분말의 식품산업 활용 측면에서 수분 흡수지수(WAI) 및 수분용해지수(WSI)는 중요한 가공적성 요인으로 알려져 있으며(29), 수분흡수지수의 경우 분무건 조 미세캡슐 분말에서 2.40 2.65로 동결건조 분말 2.66에 비해 낮은 흡수지수를 나타내어 분무건조 미세캡슐 분말에 서 저장 안정성이 높을 것으로 사료되며, 키토산 함량이 증가함에 따라 수분흡수지수가 높게 나타났다. Ko등(30)은 건조방법에 따른 표고버섯분말의 흡습특성에서 수분흡수 
지수는 동결건조가 열풍건조에 비해 높았다고 보고하여 본 연구결과와 유사하였다.

수분용해지수는 분무건조 미세캡슐 분말에서 9.17 $10.89 \%$ 로 동결건조 분말 $7.12 \%$ 에 비해 높은 용해지수를 나타 내었으며, 동결건조 분말 및 알긴산 단독 첨가에 비해 키토산 함량이 증가할수록 수분용해지수가 높게 나타남을 확인하였 다. 미세캡슐의 입자크기가 작아질수록 수분용해지수가 높아 지는 경향을 나타내었는데, Kum 등(31)은 품종 및 입자크기 에 따른 쌀가루의 수분흡수지수 및 수분용해지수 측정결과 입자크기가 작을수록 수분흡수지수 및 수분용해지수가 증가 한다고 보고하였으며, Choi 등(32)의 흑미의 입자크기 및 제분 조건에서 입자가 작을수록 수분용해지수가 $3.70 \%$ 에서 $16.30 \%$ 로 증가 한다고 보고하여 본 연구결과와 유사한 경향 을 나타내었다. 이는 분무건조 미세캡슐 분말 제조시 열처리 를 통해 백미의 전분분자를 손상시켜 수용액과 분말이 쉽게 결합 한 것으로 판단되며, 키토산 함량이 증가할수록 입자 크기가 낮아져 수분 용해지수가 증가한 것으로 사료된다.

Table 3. Water absorption index and water solubility index of the rice powders fermented with Bacillus subtilis CBD2

\begin{tabular}{ccc}
\hline Sample $^{1)}$ & $\begin{array}{c}\text { Water absorption index } \\
\text { (WAI) }\end{array}$ & $\begin{array}{c}\text { Water solubility index } \\
\text { (WSI, \%) }\end{array}$ \\
\hline FD & $2.66 \pm 0.03^{\mathrm{a} 2)}$ & $7.12 \pm 0.40^{\mathrm{d}}$ \\
SD-A & $2.40 \pm 0.08^{\mathrm{b}}$ & $9.17 \pm 0.10^{\mathrm{c}}$ \\
SD-ACh0.3 & $2.41 \pm 0.02^{\mathrm{b}}$ & $9.28 \pm 0.38^{\mathrm{c}}$ \\
SD-ACh0.5 & $2.53 \pm 0.08^{\mathrm{ab}}$ & $9.70 \pm 0.12^{\mathrm{b}}$ \\
SD-ACh1.0 & $2.65 \pm 0.03^{\mathrm{a}}$ & $10.89 \pm 0.24^{\mathrm{a}}$ \\
\hline
\end{tabular}

${ }^{1)} \mathrm{FD}$, freeze-dried powder; SD-A, spray-dried powder with $1.0 \%$ alginic acid added; SD-ACh0.3, spray-dried powder with $1.0 \%$ alginic acid and $0.3 \%$ chitosan added; SD-ACh0.5, spray-dried powder with $1.0 \%$ alginic acid and $0.5 \%$ chitosan added and SD-ACh1.0, spray-dried powder with $1.0 \%$ alginic acid and $1.0 \%$ chitosan added. ${ }^{2}$ Means $\pm \mathrm{SD}(\mathrm{n}=3)$ in each column (a-d) followed by the same letter do not significantly differ $(\mathrm{p}<0.05)$

\section{분말의 생균수 및 amylase 활성}

백미 발효물을 이용한 동결건조 및 분무건조 미세캡슐 분말의 생균수 및 amylase 활성을 Table 4에 나타내었다. 생균수는 동결건조 분말에서 $7.01 \log \mathrm{CFU} / \mathrm{g}$ 으로 가장 높게 나타났으며, 분무건조 미세캡슐 분말간의 생균수는 4.46 4.62 $\log \mathrm{CFU} / \mathrm{g}$ 로 유의적인 차이를 나타내지 않았다. Amylase 활성은 동결건조 분말에서 $506.02 \mathrm{unit} / \mathrm{g}$ 으로 유의 적으로 높게 나타났으며, 키토산 $1.0 \%$ 첨가 분무건조 미세 캡슐 분말에서 196.63 unit/g으로 활성이 가장 낮게 나타났 다. 알긴산 단독 첨가군의 활성은 $268.57 \mathrm{unit} / \mathrm{g}$ 이었으며, 키토산 첨가량이 증가함에 따라 활성이 낮아지는 경향을 나타내었다. Yang 등(19)의 Bacillus subtilis를 이용한 곡류 발효 분말의 생균수 및 amylase 활성이 각각 6.89 7.14 log $\mathrm{CFU} / \mathrm{g}$ 및 152.27 506.02 unit/g으로 본 연구와 유사한 활성 을 나타내었다. 식품산업에서 동결건조는 건조후의 복원성
이 우수하여 널리 활용되고 있으나 Kim 등(33)의 연구에서 효소식품을 동결건조 하는 경우 장시간 건조에 따른 효소 실활이 일어날 수 있다고 보고하였다. 특히 동결건조 분말 은 효소의 저장 및 섭취과정에서 열과 강산, 강알칼리에서 효소 활성이 불안정하므로 $\mathrm{pH}$ 및 온도 등의 영향에 대한 안정성 향상을 위해 알긴산 및 키토산 피복물질을 통해 효소 의 저장성 및 인체 내 안정화가 용이할 것으로 사료된다.

Table 4. Viable bacteria cell and amylase activity of the rice powders fermented with Bacillus subtilis CBD2

\begin{tabular}{ccc}
\hline Samples ${ }^{1)}$ & $\begin{array}{c}\text { Viable bacteria cell } \\
(\log \text { CFU/g) }\end{array}$ & $\begin{array}{c}\text { Amylase activity } \\
\text { (Unit/g) }\end{array}$ \\
\hline FD & $7.01 \pm 0.09^{\mathrm{a} 2)}$ & $506.02 \pm 19.88^{\mathrm{a}}$ \\
SD-A & $4.61 \pm 0.09^{\mathrm{b}}$ & $268.57 \pm 16.57^{\mathrm{b}}$ \\
SD-ACh0.3 & $4.62 \pm 0.07^{\mathrm{b}}$ & $258.66 \pm 14.21^{\mathrm{b}}$ \\
SD-ACh0.5 & $4.54 \pm 0.06^{\mathrm{b}}$ & $200.73 \pm 7.71^{\mathrm{c}}$ \\
SD-ACh1.0 & $4.46 \pm 0.12^{\mathrm{b}}$ & $196.63 \pm 9.39^{\mathrm{c}}$ \\
\hline
\end{tabular}

${ }^{1)} \mathrm{FD}$, freeze-dried powder; SD-A, spray-dried powder with $1.0 \%$ alginic acid added; SD-ACh0.3, spray-dried powder with $1.0 \%$ alginic acid and $0.3 \%$ chitosan added; SD-ACh0.5, spray-dried powder with $1.0 \%$ alginic acid and $0.5 \%$ chitosan added; and SD-ACh1.0, spray-dried powder with 1.0\% alginic acid and 1.0\% chitosan added. ${ }^{2}$ Means \pm SD ( $\left.n=3\right)$ in each column (a-c) followed by the same letter do not significantly differ $(\mathrm{p}<0.05)$.

분말의 인체 내 소화모델(in vitro)

동결건조 및 분무건조 미세캡슐 분말의 인체 내 in vitro 소화모델 분석을 통해 인체 내 이용률 및 안정화 정도에 대한 분석 결과를 Fig. 2에 나타내었다. 분무건조 미세캡슐 분말의 in vitro 소화모델을 확인하기 위해 muti-step model 의 방법을 이용하였으며, 이는 각각의 소화 단계별로 식품 소재의 bioavailability를 측정할 수 있을 뿐만 아니라 인체의 소화조건과 매우 유사하다는 장점을 가지고 있다(18). 모든 분말은 위장액(pH 1.2)에서 활성을 나타내지 않았으며, 키 토산을 $0.3 \%$ 첨가한 분무건조 미세캡슐 분말은 소장액 $(\mathrm{pH}$ 6.8)에서 269.14 unit $/ \mathrm{mL}$ 의 활성을 나타내었다. 특히 대장액 (pH 7.4)에서 222.28 unit $/ \mathrm{mL}$ 의 활성을 유지하여 백미 발효 물의 섭취 후 위장 환경에서 생리활성을 읺지 않고 이를 소장 및 대장에서 방출되었으며, 최종적으로 $85.93 \%$ 의 인 체 내 이용률을 통해 안정화 효과가 가장 잘 이루어진 것으 로 나타났다. 동결건조 분말의 경우 소장액 $(\mathrm{pH}$ 6.8)에서 활성이 $39.31 \mathrm{unit} / \mathrm{mL}$, 대장액(pH 7.4)에서 $152.57 \mathrm{unit} / \mathrm{g}$ 으 로 초기 활성 대비 $30.15 \%$ 의 인체 내 이용률을 나타내어 분무건조 미세캡슐 분말에 비해 활성이 낮게 나타났다. 이 는 Hari 등(34)의 insulin 함유 비드 제조에서 알긴산 단독 첨가군에서 $43 \%$ 의 유효물질을 함유하고 있었으나, 키토산 을 $0.3 \%$ 함유한 다음 유효물질 함량이 $70 \%$ 로 증가한다고 보고하였다. 또한, Chang 등(35)은 효소 특성 개선을 위한 $\beta$-glucosidase의 효소 고정화 연구에서 키토산 비드 제조시 높은 $\mathrm{pH}$ 와 고온에서 비고정 효소보다 안정성이 증가한다 
고 보고하였다. in vitro 소화 모델을 통하여 각 소화기관별 백미 발효 분말의 인체 내 소화모델을 확인 한 결과, 분무건 조 미세캡슐 분말은 위액에서 안정하게 통과하여 소장 및 대장에서 amylase 활성을 나타냄을 확인하였다. 즉, amylase함유 백미 발효 분말을 섭취한 다음 위장의 낮은 $\mathrm{pH}$ 에서 효소활성을 잃지 않고 소장 및 대장에서 안정적으 로 흡수 가능한 분말 제조가 가능 할 것으로 사료되며, 본 연구에서 제조된 분무건조 미세캡슐 분말은 알긴산의 위장 관 체류시간 연장과 일정한 방출효과를 가지는 키토산에 의해 산성 조건에서의 효소활성을 보호하며 인체 내 이용률 향상을 통해 효소식품 및 서방성 약물 전달체로서의 응용연 구에 크게 활용될 수 있을 것으로 사료된다.

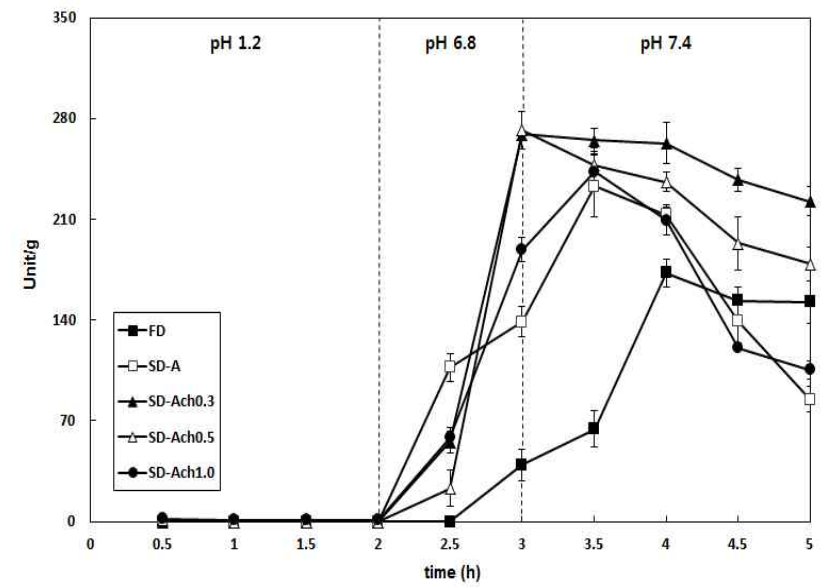

Fig. 2. In vitro release profiles of the rice powders fermented with Bacillus subtilis CBD2: Dissolution behavior in the simulated $\mathrm{pH}$ 1.2, $\mathrm{pH}$ 6.8. and $\mathrm{pH} 7.4$.

FD, freeze-dried powder; SD-A, spray-dried powder with $1.0 \%$ alginic acid added; SD-ACh0.3, spray-dried powder with $1.0 \%$ alginic acid and $0.3 \%$ chitosan added; SD-ACh0.5, spray-dried powder with 1.0\% alginic acid and $0.5 \%$ chitosan added; and SD-ACh1.0, spray-dried powder with 1.0\% alginic acid and $1.0 \%$ chitosan added. The data are expressed as means \pm SD $(n=3)$.

\section{요 약}

본 연구에서는 백미 발효물을 곡류 효소함유 식품으로 개발하고자 Bacillus subtilis CBD2를 접종하여 96시간 발효 한 다음 알긴산 및 키토산을 피복물질로 사용하여 분무건조 미세캡슐 분말을 제조하였고, 분말의 물리화학적 특성 및 amylase 활성을 조사하였다. 백미 발효물의 생균수, $\mathrm{pH}$ 및 amylase 활성은 각각 $7.61 \log \mathrm{CFU} / \mathrm{mL}, \mathrm{pH} 5.08$ 및 159.43 unit $/ \mathrm{mL}$ 이었다. 백미 발효물의 미세캡슐 분말 제조는 알긴 산 $1.0 \%$ 및 키토산을 각각 $0.3 \%, 0.5 \%, 1.0 \%$ 를 첨가하여 분무건조 하였다. 분무건조 미세캡슐 분말의 수분함량은 2.90 3.68\% 였으며, 색도는 키토산 첨가량이 증가함에 따라 $\mathrm{L}$ 값 및 $\mathrm{a}$ 값은 감소하고, $\mathrm{b}$ 값 및 $\triangle \mathrm{E}$ 값은 상대적으로 증가하 였다. 입자크기는 분무건조 미세캡슐 분말에서 48.13
$68.48 \mu \mathrm{m}$ 로 동결건조 분말 $357.87 \mu \mathrm{m}$ 보다 작았으며, 표면 구조는 전반적으로 구형을 나타내었으나, 키토산 함량이 증가함에 따라 표면 굴곡이 증가하였다. 수분흡수지수는 분무건조 미세캡슐 분말에서 2.40 2.65로 동결건조 분말 2.66에 비해 낮은 흡수지수를 나타내었으며, 수분용해지수 는 분무건조 미세캡슐 분말에서 9.17 10.89\%로 동결건조 분말(7.12\%)보다 높게 나타났다. 생균수 및 amylase 활성은 동결건조 분말에서 각각 $7.01 \log \mathrm{CFU} / \mathrm{g}$ 및 $506.02 \mathrm{unit} / \mathrm{g}$ 으 로 나타났으며, 분무건조 미세캡슐에서는 각각 4.46 4.62 $\log \mathrm{CFU} / \mathrm{g}$ 및 196.63 268.57 unit/g으로 나타나 동결건조 분말 보다 낮게 나타났다. 분말의 인체 내 소화 모델에서, 모든 분말은 $\mathrm{pH} 1.2$ 의 인공위액에서 활성을 나타내지 않았 으며, 최종적으로 $\mathrm{pH}$ 7.4의 대장조건에서 알긴산에 $0.3 \%$ 의 키토산을 첨가한 분무건조 미세캡슐 분말이 $85.93 \%$ 의 amylase 활성을 나타내어 인체에서의 높은 이용률이 기대 되었다.

\section{감사의 글}

본 연구는 교육부와 한국연구재단의 지역혁신창의인력 양성사업으로 수행된 연구결과임 (No.2013H1B8A2032215).

\section{References}

1. Park YG, Park MY, Sung MK, Kwon HJ (2005) Study on the intake pattern of health intended foods depending on inclusion of proclaimed health functional food materials. J Korean Soc Food Sci Nutr, 34, 374-379

2. Moon HP (2010) Food crisis and the importance of rice, Food Preserv Process, 9, 39-48

3. Kum JS (2010) Nutition of rice and rice processing food, Food Preserv Process, 9, 38-54

4. Kim CH, Lee SH (2011) Isolation of bacillus subtilis CK-2 hydrolysing various organic materials. J Life Sci, 21, 1716-1720

5. Santos AMP, Oliveira MG, Maugeri F (2007) Modelling thermal stability and activity of free and immobilized enzyme as a novel tool for enzyme reactor design. Bioresource Technol, 98, 3142-3148

6. Khoshnevisan K, Bordbar AK, Zare D, Davoodi D, Noruzi M, Barkhi M, Tabatabaei M (2011) Immobilization of cellulase enzyme on superparamagnetic nanoparticles and determination of its activity and stability. Chem Eng J, 171, 669-673

7. Han MW, Yoon KS (2009) Quality characteristics of 
spray drying microparticulated calcium after wetgrinding. Korean J Food Sci Technol, 41, 657-661

8. Reinccius GA (1991) Carbohydrates for flavor encapsulation. Food Technol, 45, 144-150

9. Hogan SA, McNamee BF, O'Riordan ED, O'Sullivan $M$ (2001) Emulsification and microencapsulation properties of sodium caseinate/carbohydrate blends. Int Dairy J, 11, 137-144

10. Shin SI, Lee BJ, Lee TS, Heo BU, Ryu SG (1996) Sustained release matrix tablet containing sodium alginate and excipients. J Kor Pharm Sci, 26, 187-192

11. Youm KH (2003) Properties for Biocatalyst immobilization of alginate-chitosan coacervation gels. J Ind Sci Technol Inst, 17, 79-86

12. Majeti NV, Kumar R (2000) A review of chitin and chitosan applications. Reactive and Functional Polymers, 46, 1-27

13. Ha BJ (2006) Studies on the physico-chemical properties of cleansing cosmetics containing enzyme immobilized chitosan beads. J Beau Technol, 2, 135-149

14. Bae EK, Kim GH (2008) Encapsulation of avocado oil using spray drying. Korean J Food Sci Technol, 40, 303-310

15. Yang SJ, Lee DH, Park HM, Jung HK, Park CS, Hong JH (2014) Amylase activity and characterization of Bacillus subtilis CBD2 isolated from Doenjang. Korean J Food Preserv, 21, 286-293

16. Miller GL (1959) Use of dinitrosalicylic acid reagent for determination of reducing sugar. Anal Chem, 31, 426-428

17. Phillips RD, Chinnan MS, Granch AI, Miller J, Mcwatters $\mathrm{KH}$ (1998) Effects of pre-treatment on functional and nutritional properties of cowpea meal. J Food Sci, 53, 805-809

18. Hur SJ, Lee SK, Kim YC, Choi IW (2012) Development of in vitro human digestion models for health functional food research. Food Sci Ind, 45, 40-49

19. Yang SJ, Kim YC, Hong JH (2014) Cultural characteristics and biological activities of cereals fermented by Bacillus subtilis CBD2. J Chitin Chitosan, 19, 277-284

20. Choi SH, Lee SJ (2014) Quality characteristics of Korean wheat bread prepared with substitutions of naturally fermented rice starters. Korean J Culinary Res, 15, 100-119

21. Park HS, Kim BH, Choi HS, Kim JM, Kim MK (2010) Enzyme activity of basidiomycetes products in each cereals. J Mushroom Sci Prod, 8, 102-108

22. Beom HJ, Kang DJ, Lee BD, Shon JH, Im JS, Eun JB (2007) Physicochemical characteristics of powder from hot air and freeze dried leaves and roots of Acrous calamus L.. J Korean Soc Food Sci Nutr, 36, 1451-1457

23. Lee NY (2013) Starch and quality characteristic of
Korean rice cultivar with waxy and non-waxy type. Korean J Crop Sci, 58, 226-231

24. Kang YC, Choi KK, Kim KH, Kim HK (2002) Microencapsulation of Aster scaber and Aster glehni by spray drying. Korean J Food Preserv, 9, 212-220

25. Lee MH, No HK (2002) Effect of chitosan on shelf-life and quality of wet noodle. J Chitin Chitosan, 7, 14-17

26. Kim BH, Park JW, Woo MJ (2006) Studies on the mass-production system for making biodegradable film based on chitosan/gelatin blend. J Korea Soc Packaging Sci Technol, 12, 117-123

27. Park HM, No HK, Lee SH, Yoon KS, Park CS, Hong JH (2013) Quality characteristics of microencapsulated B-carotene prepared by different molecular weight chitosan. J Chitin Chitosan, 18, 26-31.

28. Kim JW, Park IK, Yoon KS (2013) Phytochemical compounds and quality characteristics of spray-dried powders with the blanching condition and selected forming agents from pressed extracts of Ligularia fischeri leaves. Korean J Food Preserv, 20, 659-667

29. Moon JH, Kim R, Choi HD, Kim YS (2010) Nutrient composition and physicochemical properties of Korean taro flours according to cultivars. Korean J Food Sci Technol, 42, 613-619

30. Ko JW, Lee WY, Lee JH, Ha YS, Choi YH (1999) Absorption characteristics of dried shiitake mushroom powder using different drying methods. Korean J Food Sci Technol, 31, 128-137

31. Kum JS, Lee HY (1999) The effect of the varieties and particle size on the properties of rice flour. Korean $\mathbf{J}$ Food Sci Technol, 31, 1542-1548

32. Choi BK, Kum JS, Lee HY, Park JD (2006) Physicochemical properties of black rice flours (BRFs) affected by milling conditions. Korean J Food Sci Technol, 38, 751-755

33. Kim SS, Kim SY, Lee WJ (1998) Microwave vacuum drying of germinated brown rice as a potential raw material for enzyme food. Korean J Food Sci Technol, 30, 1107-1113

34. Hari PR, Chandy T, Sharma CP (1998) Chitosan/ calcium-alginate beads for oral delivery of insulin. J Appl Polym Sci, 59, 1795-1801

35. Chang J, Park IH, Lee YS, Chung SY, Fang SJ, Chandra MS, Choi YL (2010) Immobilization of $\beta$-glucosidase from Exiguobacterium sp. DAU5 on chitosan bead for improved enzymatic properties. J Life Sci, 20, 1589-1594 